\title{
Heidegger and Carnap on the Overcoming of Metaphysics
}

11th August 2005

\begin{abstract}
Carnap's famous demonstration of the "nonsensical" character of certain sentences from Heidegger's Was ist Metaphysik? has generally not been read as a serious engagement with or criticism of Heidegger's thought. I argue to the contrary. I show, first, that Heidegger and Carnap are both reacting against the same features of Husserl's system, for the same reasons, and, second, that Carnap understood this. I conclude that Carnap is criticizing Heidegger for carrying out their common project incorrectly.
\end{abstract}

In his "Überwindung der Metaphysik durch logische Analyse der Sprache" (1931), Carnap chooses, as examples of metaphysical nonsense, certain sentences from Heidegger's Was ist Metaphysik? (Heidegger, 1969). This has not normally been taken as a serious encounter with Heidegger's thought. ${ }^{1}$ I wish to argue, on the contrary, that Carnap indeed has a serious understanding and criticism of Heidegger. To this end I will show, first, that both Heidegger and Carnap are reacting against Husserl's philosophical system, in similar ways and for similar reasons. And I will claim, furthermore, that Carnap understands this, and that he therefore criticizes Heidegger for carrying out their common project incorrectly.

What Heidegger and Carnap both saw, correctly, is that Husserl solves certain problems in Kant's theoretical philosophy by in effect reconstituting pre-Kantian metaphysics within the framework of Kantian epistemology. This horrified them, and for exactly the reason it would have horrified Kant: because, namely, it meant shoring up the theoretical philosophy's demonstration of the possibility of science at the expense of the practical philosophy's demonstration of the possibility of freedom. Each, in response, put forward a new and improved version of the original Kantian strategy: a new explanation of how science is possible which would once and for all rule out the return of traditional metaphysics, and thereby once and for all protect the possibility of ethics.

To see this in detail, I will begin with a brief look at traditional metaphysics, at Kant's reasons for rejecting it, and at the way Husserlian phenomenology served to reverse and undermine Kant.

\section{What is metaphysics (and why does it need overcoming)?}

Traditional ontology ${ }^{2}$ is a hierarchy, the elements of which are the highest genera of beings: the most universal kinds of beings whose members share, strictly speaking, a common essence. Among such highest genera, there are 
several fundamental ones, namely the highest genera of substances. The hierarchy therefore has a double structure. To each highest substantial genus, first of all, there correspond a series of genera of accidents-beings which can exist only by inhering (perhaps indirectly) in a substance as substrate. But, secondly, there is a hierarchy among the substantial genera themselves, in which some are (causally) prior to others. Finally, the entire structure depends on something which is not a member of any genus, and in a sense not a being at all, called God or the One.

Each special science studies a single sphere or region of being: that is, a single highest genus of substance, along with its dependent accidental genera. Traditional metaphysicians disagree on just what such spheres there are, but perhaps the most popular answer is (in order from prior to posterior): intellect (nous) (sometimes called "spirit" [pneuma]), soul (psuchē), nature (phusis). In addition, there is a discipline of logic, which studies the analogous structure of genera found in every sphere. Finally, there is metaphysics. Metaphysics is, in a sense, simply the special science of the most prior spherei.e., "first philosophy." Because, however, of the causal dependence of all other spheres on the first one, metaphysics is also the science of the first and most universal principles (archai) and causes of being as such. In knowing that first region, in other words, the metaphysician knows all subject matters together; the metaphysician knows all beings, in particular, just insofar as they are beings-knows them, that is, with respect to their "transcendental" predicates. Metaphysical knowledge, finally, because it is transcendental knowledge, is also knowledge of the possibility of science: of each special science individually, and of science in general as a unified whole. The practitioners of each special science know the members of a certain region of being, but only the metaphysician, who knows the first causes and principles of those beings, can say why that science is possible. And because those first causes and principles belong in every case to the single, primary region, the metaphysician at the same time knows the unity of all sciences with respect to their essential ground.

Kant, as is well known, comes to this traditional system as an all-destroyer. The objects of our knowledge, he says, must be given to us in intuition. But we human beings have only sensible, not intellectual, intuition. Hence the objects of theoretical knowledge may be physical (objects of outer sense) or psychological (objects of inner sense), but they cannot be noumenal (purely intelligible). ${ }^{3}$ Metaphysics as first philosophy-the theoretical science of the supersensible-is thus not a possible (human) science.

But Kant does not therefore deny the validity of a certain kind of metaphysics. He holds that sensible things are phenomena-which is to say, that their mode of being is essentially that of appearance to creatures like us. This is an extremely defective mode of being. Its very defectiveness, however, is also what makes metaphysical knowledge about such phenomenal beings 
possible for us. To be, for them, is to be a possible object of our cognitive faculties; their transcendental predicates thus derive from the form of those faculties. Phenomenal beings, in other words, are transcendentally ideal: the form of our cognitive faculties is for them the principle and cause of being as such. Thus we can have the part of metaphysics which concerns itself with nature (with the metaphysical principles and causes-Anfangsgründeof natural science). But this metaphysics is based, ultimately, on showing the possibility of an objective consciousness (of an object for us), rather than the possibility of an object per se (an sich), and it therefore is not based on and does not form a part of a more general discipline which could claim the proud name of an ontology - a discipline which would know the first principles and causes of all beings in general.

Why did Kant want thus to destroy metaphysics while at the same time saving it? Kant believes, of course, that traditional metaphysics fails in a theoretical sense, on its own terms: it falls into contradictions. One might expect, then, that the main motive behind his project would be to combat the impression, created by that failure, that perhaps science is after all impossible-i.e., to defend us against the threat of theoretical skepticism. But, although Kant does indeed worry about the "scandal to philosophy" which that threat represents, he makes it clear, at least by the time of the B edition of the first Critique, that there is a far more important motive, having to do not with theoretical but with practical philosophy: he needs to show that human freedom, and thus human morality, is at least thinkable without contradiction.

The problem is that human beings have bodies, which is to say that the actions of a human being are physical actions of its body and that physical passions of that body cause pleasure and pain-i.e., that a human being has a private interest in a certain body. Morality, however, on Kant's analysis, involves judging (according to law) how one ought to act independently of one's private interests. The very same human being, in other words, whose will is pathological (determinable by physical passions) must also be able to issue commands which contradict those determinations. Since, however, a command cannot be valid if issued to someone unable to fulfill it, morality requires freedom - that is, the ability to act independently of physical efficient causation.

In Kant's system this is prevented from being a contradiction by transcendental idealism. Our metaphysical knowledge, in particular of causal necessity, is knowledge, not about beings per se, but about phenomena. The very act of delimitation, moreover, by which (through the faculty of reason) we come to know both the legitimacy and the limits of our metaphysical knowledge, is one which requires us already to take up the standpoint of an intelligible being. Hence when we think of a human body acting because it is acted upon (pathologically), we are indeed applying an a priori principle of universal causal necessity: without such a principle, we could not understand 
action and passion at all. But, because that principle applies only to phenomena and yields the necessity of a merely phenomenal relationship, it is not inconsistent with an independent, prior, noumenal causation by the will. This solution requires an analysis of natural causation which is in a certain sense universal and a priori, but at the same time limited (for theoretical purposes) to the natural, sensible world alone. That is: it requires that metaphysics be preserved, but only in a limited form.

We can take Kant's procedure as paradigmatic of what it means to "overcome" metaphysics. It has three important features. (I) Far from simply rejecting it, Kant explains what is right about traditional metaphysics: that the knowledge of transcendental causes and principles is a knowledge of the possibility and unity of science. But (II) he limits the scope and pretensions of this metaphysical knowledge, denying that it has its own supersensible sphere of subject matter. And (III) he does so in order to save practical philosophy, by establishing our right to think freedom and morality for practical purposesor, as he puts it, by eliminating knowledge (Wissen) to leave room for faith (Glauben) (Kant, 1990, Bxxx).

Kant's successors, however, mostly agreed that his solution leaves something to be desired, in two respects. First, the idea of an in-principle unknowable realm of Dinge an sich seemed to them absurd. Second, metaphysics of nature is allegedly possible for us because it is concerned merely with the form of our own cognitive faculties. But what are these "faculties," and why doesn't our knowledge of them itself require justification?

Husserl is one of many philosophers who face this post-Kantian problem situation. Like many of them, he tries to solve both the above problems at once by in some way identifying our knowledge about our own faculties with our understanding of the way appearances depend on Dinge an sich. His strategy is distinctive, however, in that he literally restores a sphere of necessary, supersensible being as the subject matter of first philosophy. He agrees that objects of the special sciences are phenomenal. But a phenomenon, he maintains, is not the appearing of an unknowable Ding an sich; it is just that whose being depends on its appearing to us - that is, on its being rationally posited by us, on the basis of an intentional interpretation of sense data, as existing. It follows that the principles and causes of all beings as such are the states of pure consciousness (Erlebnisse) in which such intentional interpretations take place. Phenomenology, the science of essence in the region of pure consciousness, is therefore the one science by which all special sciences are unified and by which their possibility is absolutely demonstrated, i.e. by which they are "absolutely grounded." In it,

an ascent occurs from their [i.e., the special sciences'] beginnings and grounds to the primal grounds [Urgründen], the primal beginnings [Uranfängen], the true archai. But these lie, one and all, in pure consciousness, in which every possible being [alles möglicherweise Seiende] ... 
is subjectively constituted in essentially proper formations of consciousness. (Husserl, 1956, 169) ${ }^{4}$

Phenomenology's own special subject matter, the primal region (Urregion) of pure consciousness, is a realm of absolute, necessary being, separated from all other spheres by "an abyss of sense." 5

As Kant himself would have predicted, however, this solution to the problems in his theoretical philosophy plays havoc with the basis of the practical philosophy. Husserl does allow for an objective science of ethics: just as mere things (bloße Sachen) gain objective existence by being rationally posited on the basis of an interpretation of sense data, so too can things be objectively valuable, or actions objectively desirable, insofar as they are rationally so posited on the basis of emotional and volitional data $(\S 85$, p. $173 ; \S 117$, p. 244). By this very analogy, however, it is clear that ethics so understood is just another special science, albeit of spirit (Geist), rather than of nature. By means of this science I can understand human beings (including my own self when I regard myself as a human being) as subject to duties which possibly go against their inclinations. But human beings are not thereby free in the strict Kantian sense of being autonomous. Ethical laws are possible for the same reason and in the same way as natural ones: what is objectively desirable is what necessarily appears desirable. In phenomenology we ascend from the principles and grounds of ethics to true principles and grounds in the realm of pure consciousness. ${ }^{6}$

The self which has "perfect freedom" (Husserl, 1922, §31, p. 55), on the other hand, is not, according to Husserl, this human being within the world, and its freedom is not a freedom to act in the world independently of private interest. It is the pure ego: the source of that rational positing upon which all transcendent things depend for their being. Its freedom, therefore, is a freedom to modify the direction and character of positing ( $\$ 92$, p. 192) or, ultimately, to suspend such positing altogether, to carry out the "phenomenological reduction" ( $(31$, p. 55): i.e., to annihilate the world. Because, in other words, the pure ego occupies the place reserved for God in traditional metaphysics, its freedom is divine, rather than human; its motives (if any) cannot be on a par with human inclinations or ethical principles. This divine freedom could perhaps be the basis of a kind of ethics, and even a kind of autonomy. But the ethics would be Gnostic ethics, not Kantian; the command which the transcendental subject autonomously gives itself would be: "Return to your own true infinite nature."

Husserl's system, in other words, saves the theoretical philosophy (and thus heads off the threat of theoretical skepticism) only by giving up on what Kant thought of as its primary purpose: namely, to show that the possibility of science does not contradict the possibility of freedom. From a Kantian point of view, then, the emergence of Husserl's system is a sign that metaphysics must still be overcome. 


\section{Heidegger's Attempt at Overcoming Metaphysics}

Although the phrase "overcoming of metaphysics" derives here from Carnap, we have it on Heidegger's authority that he would like it applied to his undertaking, as well: in his 1943 Afterword to Was ist Metaphysik? (in part a reply to Carnap's criticisms) he says that the title question "originates from a thinking which has already entered into the overcoming of metaphysics" (Heidegger, 1969, 43). If the above analysis is correct, we should thus look for our same three characteristics in Heidegger's project: (I) it should preserve the function of metaphysics as demonstrating the possibility and unity of science; (II) it should limit metaphysics' pretensions to having its own supersensible realm of subject matter; and (III) this should be done in order to make it possible to think human freedom.

As to (I), is it not obvious, given the title, that Heidegger does not intend to do away with metaphysics entirely? A closer look might easily lead to the opposite conclusion. For the answer to the title question turns out to be that the subject of metaphysics is-nothing. How could a field whose subject matter is nothing serve to ground and unify the special sciences?

The simple answer is: because nothing unifies and explains the possibility of all the special sciences. Heidegger begins, after all, by saying just that: that, in today's state of "disintegrated [zerfallene] manifoldness of disciplines"manifold held together only by "the technical organization of universities and faculties" and given significance, as a whole, only by "the practical positing of ends" by practitioners of the various disciplines- "the roots of the sciences in their essential ground are dead" (25). But isn't this latter a complaint about the present state of things, which Heidegger hopes to rectify? Yes and no. Heidegger does want to recover the unity of science. But when he turns to saying what the sciences actually have in common, he describes it as a "freely chosen deportment [Haltung] of human existence" (26).

Perhaps this expression seems obscure. That should come as no surprise: Heidegger is famous for his obscurity, after all. Still, a reader may reasonably expect an interpretation such as mine to clarify such obscurities, or may at least expect that interpretive work will proceed in the direction of fully clarifying them. I will try to do that to some extent. I must also point out right away, however, that such a project is philosophically problematic, and that, moreover, there is a similar problem in Carnap's case. The problem stems, in each case, from the central role that each gives to a kind of analysis of language, and thus to the demand for a kind of clarity or transparency in the use of language. I will argue, indeed, that the key issue between the two thinkers concerns precisely this: not the unity of science, or the status of logic, or the criticism of Husserl (on all of which they agree), but the question: what constitutes a responsible and therefore clear and significant use of language? In each case, the absence of certain kinds of clarity, or the absence of certain 
kinds of explanation or justification, stems in large part from the fact that those kinds of clarity are in conflict with the kind that each considers philosophically imperative: what seems like clarity to us would be condemned by them as involving an abuse of language. Their obscurity, in other words, is largely essential to their positions. One cannot say-or cannot coherently say-the same things they do, only with the obscurity removed. Any clarification on our part is therefore likely to involve either a (perhaps unrecognized) disagreement with the position in question or a (perhaps unintentional) failure of coherence.

So we should not expect that phrases such as "free deportment of human existence" can be harmlessly replaced with something clearer. Still, I will, at both of the risks just mentioned, say one thing about it, namely that it points to the possibility and unity of science as ultimately practical issues. What is essential to each of the sciences, and to all the sciences in common, is something "freely chosen" by human beings qua scientists: a certain deportment or attitude towards the world. But it turns out, then, that there is, indeed, nothing to ground and unify the special sciences other than the "practical positing of ends." Or: what grounds and unifies the special sciences is a practical unity, and, other than that-i.e., from the point of view of theory-nothing. If there is a discipline of metaphysics, then, its subject matter is nothing.

But something seems to have gone wrong here. How did we get from the claim that, from a theoretical point of view, nothing grounds and unifies the special sciences, to the conclusion that a (theoretical?) discipline which studies nothing could demonstrate their unity and possibility? One might rather think to conclude that something demonstrates the possibility of each special science, only not the same thing in each case. And yet there are independent grounds for thinking that the possibility of science is explained by "nothing."

We can best see this by beginning with Husserl's description of the theoretical attitude - that is, of the purely objective attitude appropriate to science. According to Husserl, this is the attitude in which the subject has posited an object merely as being, without carrying out any additional act (for example, of valuing). According to Husserl himself, then, the fact that "nothing" grounds and unifies the special sciences can be seen as deriving from the essential feature of objective consciousness in general. For if we look for something essential to the attitude or deportment of science, what we find is not a peculiar presence but a peculiar absence: not a something, but a nothing. Heidegger simply follows Husserl, then, when he says that, while there are many ways in which human beings deport themselves towards beings, what is unique to science is that its deportment is only towards a being: toward "the being itself - and beyond that, nothing" (26), and concludes that it is this "beyond that, nothing" which unifies science and makes it possible. But then, if metaphysics knows all beings as such (the objects of all sciences) by knowing such a grounding and unifying principle, the proper concern 
of metaphysics must be nothing. And so Heidegger asks his metaphysical question: "How stands it with this nothing?" (ibid.).

At this point we may feel a tendency to giggle. The transition either from "Nothing grounds and unifies the sciences" or from "Science studies beings, and beyond that nothing" to "How stands it with this nothing?" sounds suspiciously like a joke. It sounds, in fact, like a particular kind of joke-a pun, or a related type of wordplay. ${ }^{7}$ And it is indeed very like such a joke. Heidegger asks us, in all seriousness, to do deliberately what a pun unexpectedly forces us to do: listen to what we really said, and take responsibility for it. Science, he claims, has already betrayed itself in speech: "there, where it seeks to enunciate its own essence, it calls the nothing to its aid" (Heidegger, 1969, 27). Later, he returns to this point, now not with respect to "science" but to all of us collectively: "we do know [kennen] the nothing," he says, "even if only as that about which we every day carelessly speak" (29). The overcoming of metaphysics will rest on this demand that we must now mean (take responsibility for) what we have already carelessly said. It will rest, that is, as I have already promised above, on a method for the analysis of language. ${ }^{8}$

We might, however, concede at this point that nothing is in some way an "essential ground" of science, and still doubt that it is the proper object of metaphysics. Metaphysics was supposed to ground and unify the sciences by studying, not just any essential thing which they happen to have in common, but the first causes and principles of beings as such (the transcendental causes and principles). Is the nothing a cause and principle of being?

In Husserl's system there is a direct route, leading through logic, from general conditions on theoretical positing to general conditions on beings as such. Husserl understands logic in a traditional way: it studies "the empty form of a region [of being] in general," i.e. the analogous structure of categories which is found in every such region (see Husserl, 1922, §10, pp. 21-2). The logician therefore knows laws which apply to all beings as such. The phenomenologist, however, knows why these laws apply to all beings, because the phenomenologist can relate them to the essential possibilities for transitions between different kinds of theoretical positing (§147, pp. 305-6). From this point of view, the "beyond that, nothing" of the theoretical attitude, and the corresponding finitude common to all beings, is easily explained: it simply expresses the logical law that everything is itself and not anything else: the law that (not-not- $x)=x .{ }^{9}$ And that law, like all logical laws, has a phenomenological ground: in this case, the essential possibility of transition from the positing of $x$ to the positing of not- $x$, and then, by the very same process, back to $x$ once again.

Heidegger cannot follow this route, however, if his overcoming of metaphysics is to have feature (II). For it is a route which leads back from Husserlian logic to Husserlian metaphysics-i.e. to phenomenology as the science of the supersensible realm. He therefore makes two claims. First, that the 
transition to not- $x$ is itself made possible only by an encounter with the nothing: since a being is not-nothing before it is not-something-else, "the nothing is more primordial than the not and negation" (Heidegger, 1969, 28). Second, that this prior encounter with the nothing is not due to a faculty of ours, i.e. is not a matter of anything like positing.

To establish the latter point, he introduces the concept of mood (Stimmung), as a way of encountering the world which does not involve a faculty, and in particular a "fundamental mood" (Grundstimmung) of indeterminate unease or dread, which (following Kierkegaard) he calls Angst. In this mood "all things and we ourselves sink into indifference" (32). In Husserlian terms we might say: it is a mood in which the beings themselves that we have posited (including ourselves) do not support our further, valuing acts. ${ }^{10}$ Thus this is a mood in which we encounter beings in general, in their finitude, through a kind of encounter with the form of our faculties-not, however, in Husserl's way, by showing that those beings depend on our act of positing and that we are therefore free to annihilate them. The encounter with the finitude of beings is rather by way of an encounter with our own finitudewith, so to speak, our un-faculty-in the face of the nothing: "In Angst there occurs no annihilation [Vernichtung] of the whole of beings per se, but just as little do we carry out a negation of beings as a whole in order first to attain the nothing.... The nothing itself nihilates [nichtet]" (Heidegger, 1969, 34). And, again, Heidegger claims that we have already said this. "We say: that before which and about which we had Angst was 'actually' - nothing. In fact, the nothing itself-as such-was there" (33).

The nothing encountered in this way, however, is the very nothing that demonstrates the possibility and unity of the sciences. What threatens, in Angst, to sink into insignificance, is not any particular being or region of beings, but all beings as a whole. And it is this general threat of insignificance which makes science possible: without it, there could not be the "beyond that nothing" of the theoretical attitude, by which a being is encountered merely as itself, rather than as valuable or significant for us:

Only because the nothing is revealed can science make beings themselves into the object of inquiry. Only if science exists out of metaphysics, is it capable of continually attaining anew to its essential task. (40-41)

But the nothing encountered in Angst is also, on the other hand, what is essential to every being as such. Before a being can be itself rather than another, it must be a being rather than nothing. What belongs to beings (Seiende) simply as such, then, rather than as this or that particular being, is this relation to the nothing of beings as a whole (35). The condition of possibility of beings as such, then-i.e., the being (Sein) of beings per se-is this very same nothing.

Heidegger's overcoming of metaphysics thus fulfills our criterion (I), and at the same time also criterion (II), but in a way which avoids the problems with Kant's. It does not limit metaphysics by drawing, within the realm of 
beings, a line around the range of our cognitive faculties, and then showing that the supersensible beings which would be the subject matter of metaphysics lie outside. We do know the nothing — only, not by a faculty, i.e. not as a being; the nothing is always, with respect to any being or region of beings, the "beyond that, nothing": "neither an object, nor a being at all" (35). Whereas for Kant, in other words, the limitation of metaphysics was at the same time a limitation of science, for Heidegger, metaphysics is limited, but science is not. Science will answer every question we have about beings. It follows that we were wrong to think of metaphysics as a kind of science or theoretical discipline which is "about" nothing in the sense of having nothing as its subject matter. Since the nothing is not a being, metaphysics, which is about nothing, is not a science (41).

If metaphysics-i.e., philosophy, strictly speaking - is not a science, then what is it, and in what sense is it about the nothing? This brings us to point (III). In Sein und Zeit, Heidegger seems so clearly, and at such length, to treat of practical issues, that that book has often been mistaken for a moralizing book of ("existentialist") ethics. ${ }^{11}$ Here in Was ist Metaphysik? he is much briefer, but the nature and standpoint of the ethical concern is clearer. The overcoming of metaphysics is necessary to establish the very possibility of freedom, ${ }^{12}$ thus of morality, for a being like us (the kind of being Heidegger calls Dasein):

Abiding by itself out [sichhineinhaltend] into the nothing, Dasein is always already out beyond beings as a whole. We call this being-out beyond beings transcendence. If Dasein were not, in the ground of its essence, transcending, which now means: if it did not in advance abide by itself out [sich nicht im vornhinein ... hineinhalten] into the nothing, then it could never relate to beings, thus also not to itself.

Without primordial revelation of the nothing, no being-oneself and no freedom. (Heidegger, 1969, 35)

Sichhineinhalten is a (very unusual) verb which means literally "to hold oneself out into." But etwas einhalten means to abide by or conform to or comply with something, and is thus connected with Haltung ("deportment") and Verhaltung ("behavior"). That metaphysics is about nothing means: that the possibility and unity of science is demonstrated only in Dasein's encounter with its own un-faculty, with its own possible inability to take up a Haltung (in which, as Heidegger puts it, it finds that it sich an nichts halten kann [32]): that is, with its own possible insignificance to itself. But to know oneself as possibly insignificant to oneself is at the same time to know oneself as ultimately responsible for one's own significance. Knowing ourselves as finite, as beings among beings, we also know ourselves as having a finite interest, in pursuit of which we have already spoken carelessly (have taken no responsibility for our word). But we can know this only because we find ourselves to be commanded (or "called"), and therefore to be (possibly) free. 
What metaphysics offers is not a theory, but a demand, and the demand itself is the demonstration of our freedom: that we are free to listen to, and take responsibility for, what we have really said; to abide by the necessity of our own language, our own self-legislation as rational (i.e., speaking) beings; to abide by ourselves out into the nothing; to comply with our own finite nature. That is: that we are free to be our own (true, proper) selves-which, if you like, you could call the categorical imperative.

\section{Carnap's Alternative}

"Overcoming of metaphysics" is Carnap's phrase, and we must now justify our use of it, by showing, first, that his overcoming, too, has the three features which we identified in Kant and Heidegger, and, second, that the metaphysics being overcome in his case is also Husserl's. Since, however, the "Überwindung" itself does not contain anything like a complete system, we will have to rely also on Carnap's other writings: especially on his major early work, the Aufbau (Carnap, 1974). There is some risk involved in this procedure (because Carnap's position changed throughout the period in question), but with caution the risk can be kept to an acceptable level.

First, however, it will be useful to introduce a few more details of Husserl's system. Ontologically, it is a traditional double hierarchy. There are regions or spheres of being, and perfectly traditional ones, except that (due to Kant's "Copernican revolution") the traditional order is reversed: after the new $U r$ region of pure consciousness come the region of nature, the psychological region, and finally a region (or perhaps many regions) of Geist. Each such region is based upon a single highest genus of concrete objects ("individua"), corresponding to the traditional highest genera of substances: in pure consciousness, for example, Erlebnisse; in nature, "things" (Dinge). But each region also contains a hierarchy of abstract genera-genera of singular abstracta and of what Husserl calls "categorial" or "syntactic" objects (for example, classes and relations) (see Husserl, 1922, §§11-16, pp. 23-32). This structure of "logical modifications," found analogously in each region, is the concern of logic. In addition, however, to the "formal essence" which each object has by virtue of its position in the logical hierarchy, there are also truths of "material" (sachliche) essence, which apply to objects as members of some species or genus-ultimately, some region of being. Thus the special sciences, which are individuated (as in Aristotle) by the regions they study, are each broadly divided into two parts: a science of essence and a science of "matters of fact." 13 Finally, there are what might be called matters of metaphysical essence: necessary truths about objects which apply in virtue of their dependence on objects in prior regions, and ultimately within the Urregion of pure consciousness. 
This ontological structure translates directly into an epistemological one, because all being in the posterior regions rests on positing Erlebnisse in the realm of pure consciousness, and in particular on originary (immediate) rational theoretical positings, i.e. "intuitions." The various sciences are therefore based on various types of intuition. Sciences of matters of fact, on the one hand, correspond to the kinds of ordinary intuition, analogous to perception. Sciences of essence, on the other hand, and formal logic, correspond to (formal or material) "essential insight" (Wesensschau). Husserl equates formal- and material-essential insight, respectively, as sources of knowledge, to Kant's analytic and synthetic a priori, whereas ordinary perceptual intuition, the source of knowledge about matters of fact, corresponds to the Kantian synthetic a posteriori ( $\S 10$, p. $22 ; \S 16$, p. 31$)$. Phenomenology, finally, as the science of essence in the region of pure consciousness, has knowledge of the way beings in one region are dependent on those in another.

In Carnap's doctoral thesis, Der Raum (1922), he applies the above Husserlian apparatus to the problem of determining our sources of knowledge about space. ${ }^{14}$ Is our knowledge of space analytic, synthetic a priori, or empirical? Carnap answers, in effect: it depends on what you mean by "space." His answer foreshadows much of his future thought, but is also based directly on Husserl's remark about this question in Ideen I: that, whereas Euclidean manifold is a formal category (logical modification), our knowledge of geometry as it applies to physical objects is a knowledge of material essence within the region of nature ( $\S 13$, p. 27$)$. Der Raum is largely an expansion and explication of that one remark. Our knowledge of "formal space," Carnap says, is analytic, i.e. derives from "formal ontology in Husserl's sense," but our knowledge of the "intuitive space" in which sensible objects are necessarily found is synthetic a priori, i.e. material-essential (and here again he mentions Husserl explicitly) (Carnap, 1922, 22-3; 61; 64-5). There is one important innovation: Carnap claims that essential (a priori) knowledge of intuitive space extends only to its topological properties, whereas the full structure of physical space requires also a choice of metric. This latter choice is informed by the actual behavior of objects (e.g. measuring rods), and knowledge of physical space is thus in part a posteriori-as Carnap also says, a knowledge of "matters of fact." But such considerations never force the choice of one metric or another: our knowledge of physical space also depends on "free positing" (wahlfreie Setzung) (see again 1922, 64-5). This last point, which has no equivalent in Husserl, is important. Still more telling is that Carnap compares the choice involved here to a choice of language, although at this stage he sees this as a mere analogy. On the whole, however, the treatment of Der Raum is more or less orthodoxly Husserlian.

In the more ambitious project of the Aufbau the correspondence with Husserl's system is, if anything, even easier to trace. The overall ontological structure of regions or spheres or realms of being is nearly identical. 
Carnap's initial realm of the "autopsychological" clearly corresponds (as he explicitly points out $[1974, \S 64$, p. 86]) to Husserl's region of pure consciousness; its fundamental objects are called Erlebnisse. Next comes the physical realm, where, as in Husserl, the fundamental objects are "things." Carnap even follows Husserl on the detailed steps by which such "things" are constituted: first, a level of visual things (Sehdinge), i.e. mere colored surfaces moving in space (Husserl, 1922, §151, p. 316; Carnap, 1974, §128, p. 170); then, a narrowly "physical" level of quantitative description in which movement is determined by strict causal law (Husserl, 1922, loc. cit. and $\S 52$, pp. 97-102; Carnap, 1974, §136, pp. 180-82); finally, the level of "intersubjective" objects (though in this case, as both make clear, there is a kind of interweaving by which higher-order, psychological objects are used to complete the constitution of lower-order, physical ones) (Husserl, 1922, §151, p. 317; Carnap, 1974, $\S \S 148-9$, pp. 198-200). After the physical realm comes a "heteropsychological" one (corresponding to Husserl's psychological region), and finally a realm or realms of Geist. Carnap follows Husserl, moreover, in referring to the process responsible for this structure, by which one object is founded on another, as Konstitution (Carnap, 1974, $\S \S 1-2$, pp. 1-2).

Carnap, however, makes one fundamental departure from his Husserlian model. Where Husserl holds that there are two types of constitution-one responsible for the hierarchy of logical forms and the other for the hierarchy of regions of being-Carnap requires only the first. This, he emphasizes, is the most important thesis of his "constitution-theory," and the basis for its most important conclusion: that "the objects do not disintegrate [zerfallen nicht] into different, unconnected realms, but rather there is only one realm of objects and therefore only one science" ( $\$ 4$, p. 4; Carnap's emphasis). How, then, can he speak of separate realms of being, paralleling Husserl's regions? Carnap claims that this division is a practical one, based on the technical organization of scientific disciplines. Theoretically speaking, although every level of the constitutional system defines a new type of object (in Russell's sense), these types are equivalent to Husserl's formal (syntactic) categories: ${ }^{15}$ they are logical modifications of the basic objects. Thus the system is a logical construction of the world.

Of our three features, then, feature (I) is clearly present: there is still a discipline which serves to unify the sciences and to demonstrate their possibility. In the Aufbau this discipline is called "constitution theory"; in the "Überwindung" it is called "metalogic," although Carnap continues to use "constitution theory" in that period, as well. It demonstrates the possibility of the sciences by establishing the objectivity of their concepts: in particular, by showing how all the concepts they need could in principle be rationally applied using finite operations on a finite stream of sense data - that is, by showing how we could in principle substitute "discursive reasoning" (diskursive Schlüße) for "intuitive recognition" (intuitive Erkenntnis) $(1974, \S 54$, p. 74 ; see also $\S 100$, 
pp. 138-9; $\S 21$, p. 27; Foreword, pp. xix-xx). In other words, it establishes the right of a finite (discursive) rational being like ourselves to use all those concepts. In so doing, it also provides an even stronger unification of the sciences than does traditional metaphysics (i.e., Husserlian phenomenology), because it shows how all scientific concepts can be logically derived from, or "reduced" to, a common basis. ${ }^{16}$

If Carnap's project so effectively satisfies criterion (I), however, we might begin to worry about criterion (II). If the sciences are to be unified by tracing them all back to a fundamental realm of objects, won't the science of that realm, as it does in Husserl, now take the place of traditional metaphysics? But Carnap does not intend to ground posterior sciences by deriving their authority from that of prior ones. Rather, like Heidegger, he is interested in what the sciences as such have in common. What is to ground and unify the sciences is not some putative science of autopsychology, but rather constitution theory, and what the constitution theorist knows is not some special facts about the essence of Erlebnisse. Any knowledge of that kind would have to come from empirical psychology (Carnap, 1974, §67, pp. 91-3). Constitution theory concerns, rather, the possible logical relationships between concepts in general; the real grounding and unifying power-and this becomes, if anything, even clearer when the discipline is called "metalogic"-comes from logic. And Carnap, like Husserl, holds that logic "is not its own realm at all," but treats of "just those concepts which allow of being applied to any arbitrary realm" $\left(\S 154\right.$, p. 207). ${ }^{17}$

There is a worry remaining, however, similar to the problem that Heidegger faces at this juncture. It is all very well to say that logic has no realm of its own, and nevertheless applies to objects in any realm whatsoever. But Husserl has a phenomenological explanation for that: logic applies in any realm because it derives from the most basic essential facts about theoretical positing. Logic is therefore a dangerous ally for Carnap, as it is for Heidegger. Unless he is careful, an appeal to logic may end up being an appeal to Husserlian phenomenology, after all—or rather: constitution theory, which is supposed to use logic to demonstrate the unity of the sciences, may itself end up being (a branch of) phenomenology.

As we saw above, Heidegger's response to this problem is to claim that his "nothing" is prior to, and presupposed by, logic - a precondition of (in Husserl's terms) all theoretical positing, but not itself the object of such positing, i.e. not a being. This, according to him, is why nothing unifies the sciences, and why metaphysics is about nothing-i.e. not about beings, not a science. Carnap's approach appears on the surface quite different. He denies, first of all, that the truths of logic derive from basic facts about theoretical positing, and claims, instead, that they are true because of their form, i.e. because of the rules of our language (see Carnap, 1974, $\S 107$, p. 150; 1931, 236). Thus, already in the Aufbau, he is committed to the idea that "con- 
stitution theory" is a science, indeed, but a science whose subject matter is language. Its legitimation of scientific concepts is really just a demonstration that scientific terms are meaningful: all objects which are studied in science must be constitutable, because "otherwise their names would have no sense" (1974, $\S 179$, p. 252). Similarly, the task of unifying the sciences is really the task of showing that "science, according to the logical meaning [Bedeutung] of its statements, treats of only one realm" ( $\S 41$, p. 56).

But language, for Carnap, is a finite, contingent, empirical thing. ${ }^{18}$ Hence if the possibility and unity of science can be demonstrated by clarifying the logical relationships between our concepts, and if those logical relationships, in turn, can be explained as (formal and empirical) truths about a language, we can have the grounding and unifying functions of metaphysics without allowing any realm of necessary, supersensible being. As in Heidegger, moreover, this limitation of metaphysics involves no line, drawn within the realm of beings, between the knowable and the unknowable. The line is drawn within language, between sense and nonsense. The limitation of metaphysics puts no limit on science, which, "within its dimension, runs up against no bounds" (Carnap, 1974, $\S 180$, p. 253): every theoretical question which can be asked at all can be answered within science.

But - and this will lead us to criterion (III) - language is conventional. Logic, if it consists of statements which are true by virtue of the rules of our language, therefore "consists only of conventional stipulations about the use of signs and of tautologies on the basis of these stipulations" ( $\S 107$, p. 150). Having, in other words, reduced all of Husserl's necessities to logical necessity, and logical necessity to linguistic, Carnap is left with only two of the sources of knowledge which he recognized in Der Raum: besides empirical (a posteriori) data as the basis for the knowledge of matters of fact, there is only wahlfreie Setzung. "According to the view of constitution theory there are no other components of knowledge besides these two: the conventional and the empirical; thus, no synthetic a priori” $(\S 179$, p. 253$)$.

It follows, however, that we were wrong, strictly speaking, to think of metalogic or constitution theory as taking over the functions of metaphysics. The problems of the disunity and ungroundedness of science are problems about the language chosen by science. Science, "in its practical procedure," makes statements which, "according to [their] logical form ... have to do with many self-sufficient kinds of object" ( $\S 41$, p. 56). As scientific statements, these are (by the definition of "science") all legitimate, which is to say (in this period): they can all be transformed into statements about a common empirical basis. The problem is that the language we have so far used to express them does not make that clear. This is not a theoretical problem. To solve it, we do require the services of a discipline which studies the possible forms of language, and which will show how a language could exhibit, in its very form, the unity and legitimacy of scientific statements. Only given a "unified system 
of all concepts," i.e. a unified language, can we "overcome" (überwinden) the "disintegration" (Zerfall) of science into disconnected disciplines ( $\$ 2$, p. 3$)$. But the overcoming itself is not a language or a theory of language. It is a free positing, a stipulation, a choice: the choice to translate, or attempt to translate, our statements into that formally grounded and unified language - the choice to subject our statements to "logical analysis." What replaces metaphysics is strictly speaking something practical:

What still remains over at all for philosophy, if all sentences which mean [besagen] anything are of an empirical nature and belong to positive science [Realwissenschaft]? What remains are no sentences, no theory, no system, but only a method, namely the [method] of logical analysis. (Carnap, 1931, 237)

For Carnap, in other words, as much as for Heidegger, it turns out that scientific philosophy strictly speaking is not itself a science.

Note that none of this would make sense if, as is often supposed, Carnap's logical analysis aimed to reveal the true, "deep" structure of our ordinary language (as opposed to its "surface grammar"). Analysis such as that would no more lie beyond the realm of theory than does, say, archeology. But Carnap does not believe in "deep" structure. Logical analysis, according to him, can only be a project of translating one language into another one: into a logically correct language, which, though stricter, is not deeper (or more "primordial": cf. Der Raum, 65). Thus logical analysis can purify our language of (practical) error, but it can never reveal more about its structure than does ordinary ("surface") grammar. This will be important to keep in mind in what follows (and may also help throw light on the differences between Carnap and Wittgenstein). ${ }^{19}$

We have now seen that Carnap's project of overcoming of metaphysics is ultimately a practical, not a theoretical, task. But is it motivated by the desire to save practical philosophy in a Kantian sense, i.e. to remove the metaphysical errors which seem to rule out the possibility of freedom? Consider, first, the Foreword to the Aufbau, which begins precisely with a question about motives: "What is the goal of a scientific book?", and continues:

It presents thoughts and tries [will] to persuade the reader of their validity. But beyond that, the reader also wants to know: from where do these thoughts come, and where do they lead? ... Here, outside the borders of theory, an answer to the second question may be attempted in brief hints. (Carnap, 1974, Foreword, xvii)

From this we can already learn a crucial (and difficult) lesson about Carnap as a writer: that, when it comes to the most important matters, he speaks in brief hints. But we can learn more from reading further. The full answer to the question which opens the Foreword is provided only in its final paragraph. There Carnap begins by mentioning unspecified "movements from 
the philosophical-metaphysical and religious realms" which stand against our "attitude" (Einstellung) and which "precisely today again exert a strong influence." He continues:

What gives us, nevertheless, the confidence to press through [durchzudringen], with our call for clarity, to a metaphysics-free science? It is the insight, or, to say it more carefully, the faith that those opposing powers belong to the past.... The faith that the future belongs to [our] attitude [Gesinnung] bears up our work. (xx)

Now, it can be difficult to attach much weight to Carnap's talk of Glaube, which I have translated as "faith" — but which might just as well be translated as "belief." ${ }^{20}$ Near the end of the Aufbau, however, we find a section entitled Glauben und Wissen-which now, given the allusion to Kant, we must certainly translate as "faith and knowledge." In that section (§181), Carnap discusses the possibility of knowledge which would be non-conceptual and thus extra-scientific. "Such a possibility," he suggests, "could lie in faith [Glauben], for example on the basis of religious revelation" (p. 256). In response he distinguishes between two things which one might mean by faith. If the alleged content of faith can indeed be revealed, i.e. asserted in language, then, however we may have come to know it, it by definition belongs to the realm of science. But,

if, on the contrary, faith is not something conceptually formulable, but rather an inner deportment [Haltung] of the human being, then this has nothing whatsoever to do with the realm of theory, and the result of this deportment cannot be designated as knowledge [Erkenntnis]. (256-7)

Hence the allusion to Kant is accurate: what is meant here by "faith" in the second sense- a faith which would belong to the realm of praxis, not that of theory-is faith in the sense of Kantian religion. ${ }^{21}$

Carnap's statement that "the future belongs to our attitude," similarly, is "outside the borders of theory": it is no theoretical prediction, but a choice of fundamental deportment, or, to say it carefully, a statement of Kantian rational faith. Even more carefully: of Nietzschean rational faith. For the point is that we, we scientific philosophers, are philosophers of the future. ${ }^{22}$ Our opponents, on the other hand-those whose attitude "belongs to the past"have expressed no false doctrine: there are no philosophical doctrines, hence no false ones, to be expressed. They have, rather, made a practical error-an error in choice of language. They have chosen a language which expresses the wrong fundamental deportment, because it makes what is really a matter of Glauben appear to be one of Wissen: a language with (pseudo-)sentences which in reality serve, not "for the presentation of states of affairs," but "as an expression of a life-feeling" (Carnap, 1931, 238). These are sentences, it would seem, about the necessary, supersensible causes and principle of beings as such: the (apparent) knowledge which needs to be eliminated is that same 
Wissen which Kant tried to eliminate, and which Husserl reinstated. But here we run into Carnap's version of a problem we have already encountered in Heidegger: an explicit clarification of his target (for example, a denial that we can speak about such necessary, supersensible causes) would itself be an example of the kind of metaphysical nonsense Carnap is trying to eradicate, and would invite more such nonsense in response. Instead, speaking in brief hints, he simply chooses, apparently at random, an example of a meaningless metaphysical term: "Prinzip" (for which he later gives the Greek equivalent, $\operatorname{arch} \bar{e}$ ), as it occurs in metaphysicians' answer to "the question, what is the (highest) 'principle of the world' (or 'of things,' 'of being,' 'of beings')" (224). Thus he eliminates the apparent Wissen, though without refuting it, and makes it possible to leave room for Glauben, i.e. for freedom.

We have already seen how Carnap's overcoming of metaphysics accomplishes that. Metaphysical unity and groundedness is replaced by logical unity and groundedness, but Husserlian logic has also been replaced by a "free positing," a stipulation which we must choose: the rules of a language. ${ }^{23}$ The very possibility of science thus depends on our freedom to choose a language. But language is a finite, sensible thing, chosen by a finite (discursive) rational being. The same subject, in other words, which knows everything, also itself, only in science, and which therefore knows itself as finite, is, by the very deportment which makes science possible, also free. It is free to take responsibility for its choice of language, for its own self-legislation as a rational (i.e., speaking) being. It is free, in particular, to press through with a "call to clarity": free to choose, or intend to choose, a language in which one can assert only that which a finite rational being could legitimately assert, i.e. in which that and only that can be said at all, which can be said clearly. ${ }^{24}$ It is free, in other words, to abide by its own finite nature-which, if you like, you could call the categorical imperative. ${ }^{25}$

\section{Carnap's criticism of Heidegger}

We have now established most of what we need to. Carnap and Heidegger, as we have seen, are reacting against a common intellectual backgroundreacting against it for the same reasons and in nearly the same way. Suppose that Carnap was aware of this. Might he not have had serious reasons for preferring his own version, and might he not have expressed them, if only in brief hints? It remains only to show that this is indeed the case.

Consider, first, the selection from Was ist Metaphysik? which Carnap actually chooses to quote:

What is to be researched is the being [das Seiende], and other than thatnothing; the being alone and more than that-nothing; only the being and beyond that—nothing. How stands it with this nothing? ... Is there 
the nothing only because there is the not, i.e. negation? Or is it the reverse? Is there negation and the not only because there is the nothing? ... We claim: The nothing is more primordial that the not and negation.... Where do we seek the nothing? How do we find the nothing? ... We know the nothing.... Angst reveals the nothing.... That before which and about which we had Angst was 'actually' - nothing. In fact: the nothing itself-as such—was there... How stands it with the nothing? ... The nothing itself nihilates. ${ }^{26}$

The sentences quoted do not occur all together in Heidegger. Nor, however, are they merely a random selection of sentences, or of ones which happen to sound particularly nonsensical. They are, rather, as we have seen above in detail, sentences which express the key points of Heidegger's strategy, and moreover in such a way as to show most clearly how close it is to Carnap's own. This selection, in other words, is not the work of someone casually leafing through a silly book in search of some nonsense to mock: it is the work of a thoughtful reader out to find the exact error in a potentially tempting alternative to his own approach.

And what, according to Carnap, is that error? These examples, according to him, show how "historico-grammatical syntax" allows metaphysical nonsense, whereas "logical syntax" does not (229). Here he has indeed put his finger on the most basic difference between Heidegger and himself. He and Heidegger agree that traditional metaphysics involves a practical, not a theoretical error; that it must therefore be overcome by a philosophical method; and that that method is a method of analysis of language. But where Heidegger's analysis involves listening to (and taking responsibility for) what our language, in our careless everyday use of it, already actually says-i.e., involves paying attention to "historico-grammatical syntax"-Carnap's "logical syntax" is a matter of choosing a new, correct language into which we will attempt to translate all of our old statements.

That this is Carnap's intent becomes clear when he goes on to offer his detailed critique. The centerpiece is a table with three columns, of which the key part is as follows:

A. There is rain outside. There is nothing out- There is not... some$d r(R e) \quad$ side. $\quad$ thing which is outside.

$$
d r(N i) \quad \sim(\exists x) \cdot d r(x)
$$

B. How stands it with this

How stands it with this rain? (i.e.: what is the rain doing? or: what nothing?

[The equivalent] cannot else can be stated about be formed at all. ${ }^{27}$ this rain?) ?(Re) $?(N i)$

The first column contains perfectly good sentences of "customary" (üblich) language, whereas the second column shows a transition, in that same cus- 
tomary language, from a sensible sentence to a senseless pseudo-sentence. The third column is supposed to contain sentences in a "logically correct language" which correspond to those in the second column; when we get to row B, however, we find that there is none. Carnap remarks that the sentences in the first column are "grammatically in perfect analogy" to those in the second, and that the transition from A and B occurs via "grammatically unobjectionable operations" (229). That is: he agrees that Heidegger has uncovered something real about our customary language, about what we have already carelessly said. The grammatically allowed structures and transitions (formation rules and transformation rules) of that language do, indeed, commit us to accepting Heidegger's metaphysical question: this (meaningless) question, in other words, belongs syntactically to the content of our ordinary sentences. $^{28}$

It is worth stressing that Carnap agrees with Heidegger up to this point, if only because some interpreters who see themselves as defending Heidegger against his attack have ended up taking the opposite side. James Conant, for example, claims that Carnap's attack stumbles on the need to rule out the possibility that Heidegger might intend, either all along or after some point, "to use the word "nothing' in a linguistically innovative ... manner" (2001, 35). Stephan Käufer, similarly, defends Heidegger's strange talk about the nothing based on the fact that "language is flexible and easily accommodates new terms and definitions" (2001, 472). Language is indeed flexible; linguistic innovation is indeed possible. If we knew nothing about Heidegger's linguistic methods, it would certainly be hard to rule out that that is what he intends here, and if we supposed that Carnap knows nothing about those methods, then it would be hard to defend him against the charge that he is reading Heidegger "uncharitably." In reality, however, nothing could be more uncharitable than to defend Heidegger's use of "nothing" here as a linguistic innovation. As we have seen, Heidegger's method rests precisely on showing us what our language already says. So, whatever role there might be for linguistic innovation in philosophy generally, ${ }^{29}$ Carnap and Heidegger are (rightly or wrongly) in agreement that it does not crop up here. To repeat: they agree (rightly or wrongly) that our customary language already commits us to these strange questions and answers about the nothing. But that, according to Carnap, just shows the Unzweckmäßigkeit of our language, i.e. of its rules (Carnap, 1931, 230).

Now, unzweckmäßig of course means "inconvenient." Here, as always, Carnap gives us the opportunity to read him as a mere technician. The problem with our language, on that reading, would be that it gives us the opportunity to fall into stupid blunders (or: "howlers"- which gives some indication of the unfortunate way logical positivism translated to Oxford). ${ }^{30}$ This would make sense if one thought that, in addition to its "surface" grammatical rules, our language also has a "deeper," logical structure: our language might be 
inconvenient in that, by virtue of the former, it makes difficult the technical aim of following the latter. But that, to repeat, is exactly what Carnap does not think. What then could be the technical error in following the rules of our language wherever they lead?

We must recall that Carnap speaks in brief hints. Unzweckmäßig does indeed mean "inconvenient," but it also means, literally, "not conformable to the end"-where by "the end" we must understand, in the absence of qualifications: the end in itself. ${ }^{31}$ The problem, in other words, is not technical, but practical. What, then, is immoral about the historico-grammatical rules of our language, which cause us to us to say-or rather, by virtue of which we have already carelessly said - that, when there is nothing outside, there is something outside, namely-nothing? Carnap speaks in brief hints. The draußen alludes to Heidegger's darüber hinaus: what we have already said, thanks to our inherited, customary language, is that there is something outside the realm of beings (outside the borders of theory). ${ }^{32}$ We can tell that we have said this because, by grammatically unobjectionable operations, we arrive at a question which proposes to us the task of saying something more about the nothing, or of determining what it does-that is, at a question which treats this nothing as a ground of synthesis, as an object. The general answers to these questions- "We know the nothing" (i.e., in the formal mode, "We can say something (more) about the nothing") and "The nothing nihilates" (i.e., "The nothing does something appropriate to it")—simply make explicit what has already been said in the question, and in the ordinary sentence which gave rise to the question. The content of "There is nothing outside," in our customary language, in other words, includes "We know the nothing" and (in effect) "The nothing nihilates." But this having-already-said, which is, so to speak, our hereditary sinfulness, must, according to Carnap, not be accepted, but overcome in faith. The attitude which belongs to the past is trapped, even against its will, into this saying - this saying which is unzweckmäßig because it expresses the attitude that we finite agents belong to the past, that we are not free, that there is no moral law. But our attitude, the attitude of faith to which the future belongs, is resolved (via the method of logical analysis) to choose a language in which such an expression will be impossible.

Carnap does, however, make a show of allowing Heidegger one way out. In light of the "gross logical errors" revealed by our reading, Carnap says,

one could come to the supposition that the word "nothing" is perhaps, in the cited treatise, supposed to have an entirely different significance than it does elsewhere. And this supposition is further strengthened when we read there further that the nothing itself as such is there in Angst. Here it appears that the word "nothing" is supposed to indicate a certain emotional condition [gefühlsmäßige Verfassung], perhaps of a religious kind, or something which grounds such a feeling [Gefühl]. (231) 
Carnap allows, that is, that Heidegger's talk about the nothing may be understood psychologically.

Now, this kind of "charitable" reading would, as I have pointed out, leave Heidegger's linguistic method in a shambles, and so from that point of view Carnap is not seriously proposing that Heidegger might be read this way. On its own, however, the suggestion that "nothing" and Angst might be used as psychological terms is by no means absurd. Indeed, Kierkegaard, from whom both the term Angst and its connection with "nothing" derive in this context, agrees with Carnap on this, as Heidegger well knows. ${ }^{33}$ In any case, we should certainly take seriously Carnap's concession that, if this proposed reading were correct, there would be no "logical" (i.e., practical) objections to Heidegger's project. We should take that seriously because Carnap himself adopts such a strategy in the final section of the Aufbau. There he explains that, although there is no question unanswerable by science, science nevertheless cannot solve the "riddles of life," because these are not actually questions, but practical problems. He gives, as his only example of such a riddle, the "riddle of death":

The "riddle of death" consists in shock [Erschütterung] at the death of a fellow human being, or in Angst before one's own death. It has nothing to do with the questions which can be posed about death.... The riddle consists rather in the task of "being done with [fertig zu werden]" the life-situation, to get over [verwinden] the shock.... Our thesis of the answerability of all questions has, indeed, a certain connection with this task of overcoming, but only one so remote that with this thesis nothing is said about whether such an overcoming is always in principle possible. (Carnap, 1974, §183, pp. 260-61) (44 $^{34}$

What is that "connection," and why is it so remote? Our thesis, the thesis of us scientific philosophers, allows us to overcome only one particular situation, one particular shock: the situation, the shock, of having inherited traditional metaphysics - the crisis which Carnap implicitly compares, in the Foreword to the Aufbau (pp. xvii-xviii), to the foundation-crisis in mathematics (because it leads to contradictions, albeit in this case to practical contradictions). ${ }^{35}$ This overcoming is the practical task-in Kantian terms, the religious task —of scientific philosophy. If Heidegger's talk of the nothing and of Angst could be read as psychological, in other words, then Carnap would accept it because it is what he himself would say.

But Heidegger, as we know, cannot possibly allow this reading. And Carnap, who understands that impossibility just as well as we do, is easily able to demonstrate it in Heidegger's text. Heidegger, he points out, claims that his question and answer about the nothing, because they lead us into contradictions, constitute a challenge to "the sovereignty of 'logic' within philosophy." (Heidegger, 1969, 36-7, cited by Carnap, 1931, 231). Here Carnap is usually read as attacking Heidegger for being against logic, whereas he himself was 
in favor of it. ${ }^{36}$ In fact, however, as we have seen, what both Heidegger and Carnap oppose is the sovereignty of logic within philosophy, i.e. the thought of philosophy, strictly speaking, as a theoretical discipline which makes assertions about its own special region of beings. The problem is not that Heidegger challenges logic, but that he thinks he can challenge it by asserting something which is not a judgment about any being, and over which logic therefore has no sovereignty. This means that, like it or not, Heidegger has in fact placed a limit on the reach of science: he has himself "come to the determination that his questions and answers are not unitable with the mode of thinking of science" (Carnap, 1931, 232). And it is due to that mistake that he remains, as Carnap says, merely one of "the numerous metaphysicians of the present or the past" (229 n. 1) -rather, that is, than becoming, as he might have, a rare philosopher of the future.

So, in summary, what is Carnap's accusation against Heidegger? He accuses him of trying to use assertions where only expression is appropriateand where, given the danger involved, even expression ought to be limited to brief hints. He accuses him, in particular, of putting himself (or leaving himself) in a position where he must treat religious dread as if it revealed a being, an object-accuses him, that is, of idolatry, or (what comes to the same thing from a Kantian point of view) of putting a theoretical dogmatics before ethics. This is a very serious criticism indeed. Without claiming (as I certainly would not) that it is one against which Heidegger could have no defense, I would point out two things about it. First, it is a criticism to which, as I understand it, Heidegger seriously and repeatedly responded. ${ }^{37}$ Second, it is a criticism which finds echoes in later members of Heidegger's own, Continental, philosophical tradition (e.g. in Levinas). This, I think, is enough to establish what I set out to here: not an attack on or defense of either Carnap or Heidegger, but simply a case for taking the one as a serious reader of the other.

If we don't end up in a position to takes sides in Heidegger and Carnap's debate, however-and surely, philosophy having moved on, it is far too late for that - then what philosophical good is our conclusion? We cannot take sides in this debate in part because it has changed from a debate into a fundamental structural fact about the philosophical world as we have inherited it. Here in the English-speaking part of that world, in particular, the stamp of Carnap's will is everywhere present. The way we "do philosophy"-the way we speak, write, publish; the way we divide our field into disciplines; the way we arrange requirements and syllabi for our students-none of this, of course, is the product of Carnap's influence alone. But there is nevertheless no corner in which his influence is not felt (and that applies, most of all, to those who in the English-speaking world attempt to study or practice Continental philosophy). If we can understand Carnap as having chosen among alternatives, and, more importantly, as having chosen for a reason, then we 
are on the road to once more attempting philosophy's always-repeated task of relating to (knowing) itself and thus becoming free. In other words, we are on the road to once again becoming philosophers.

\section{Acknowledgements}

I would like to thank Stanley Cavell, Jim Conant, Warren Goldfarb, Burt Hopkins, David Hoy, David Hyder, Mary Leng, Charles Parsons, Hilary Putnam, Alan Richardson, Paul Roth, Eric Schliesser, Joshua Schwartz, and Ori Simchen, as well as audience members at Harvard, the University of British Columbia, the University of Illinois at Springfield, Seattle University, and at the 2004 Husserl Circle meeting in Washington, D.C., for helpful comments on previous versions of this paper.

\section{Notes}

\footnotetext{
${ }^{1}$ A partial exception is Michael Friedman, who writes that Carnap's criticism is "more sophisticated and penetrating than one might expect" $(2000,11)$. But he still seems to me to concede too much, both with that "more ... than one might expect" and with his admission (in agreement, as he says, with James Conant) that Carnap fails to see how the "twisting of the German language" is "an essential part of Heidegger's philosophical method" (ibid., n. 16). Given the portrait of him which Friedman's own work has done so much to establish—namely, as a very sophisticated and penetrating thinker indeed-it would, on the contrary, be surprising to find Carnap missing something so fundamental in Heidegger. In what follows I will argue that he understands Heidegger's method very well.

${ }^{2}$ What follows is a composite picture of the tradition in the form in which it was received by Kant and (indirectly) by Husserl.

${ }^{3}$ Kant further restricts the range of theoretical science to the realm of outer sense (nature) only, for technical reasons which need not concern us here.

${ }^{4}$ Husserl, 1956 (Erste Philosophie) is based on the manuscript of Husserl's lectures in Freiburg during the Winter semester of 1923/24 (see the editor's introduction, p. xii). It was published only posthumously, but it is very likely that Carnap was exposed to some of it, since he was living near Freiburg at the time and attended Husserl's advanced seminars on phenomenology there during 1924 and 1925 (Schuhmann, 1977, 281). Heidegger at this time was already in Marburg, but was still in close contact with Husserl and presumably also familiar with his ongoing projects.

${ }^{5}$ See Husserl, 1922, §76, p. 141; §49, p. 93; §46, p. 86.

${ }^{6}$ Husserl therefore considers Kantian ethics to be "absurd." See Husserl, 1988, 403-18, especially 405 11. $21-8$.

${ }^{7}$ Cf. Carroll, 1872, ch. 7.

${ }^{8}$ Not the same, obviously, as Carnap's method. There will be plenty to say about the difference (and similarities) below, but, to anticipate: roughly speaking, Carnap will look forward (to what we ought now to say) where Heidegger looks back (to what we have said already).
} 
Both methods might also be usefully compared to the method(s) of ordinary language philosophers such as Austin and the later Wittgenstein. Heidegger's call for us to recognize what our language actually says might even seem to put him closer to that latter camp. In fact, however, I suspect that both he and Carnap are equally far from it, and for similar reasons. One indication of this is that Heidegger's method, even if it succeeds, doesn't lead to a relaxed sense of being once again at home with our own language, but rather produces (as, in a way, does a pun) a sense of our alienation from it (of our distance from its true meaning). See also Heidegger, 1993, $\S 44$ b, p. 220 , where Heidegger states that it is "the business of philosophy" to guard the power of our most elementary words, lest they be leveled into unintelligibility by "the common understanding" and thereby become a source of "pseudoproblems": a thought close to Carnap's but very distant, it seems to me, from Austin's or Wittgenstein's.

${ }^{9}$ We would tend not to consider this a law of logic, but rather, perhaps, of set theory (which we might write $\forall x(\overline{\overline{\{x\}}}=\{x\})$ ). But Husserl does not make that distinction (which, in its current form, is due to Quine). (He would agree with us, incidentally, that the complement is taken only relative to a universe: not- $x$ is an object in the same region as $x$.)

${ }^{10}$ Heidegger himself would not accept this paraphrase for various reasons, but it is not important for our present purposes to put it into correct Heideggerian terms. (It would anyway be difficult, since it seems there are some changes in precisely this area between Sein und Zeit and Was ist Metaphysik?. See especially Heidegger, 1993, §40, pp. 186-7, where the nothing before which we have Angst is explicitly said to be the nothing of innerworldly beings only, and where Angst is therefore interpreted as showing the possible insignificance only of innerworldly beings-i.e., not of beings with the mode of being of Dasein.)

${ }^{11}$ Despite explicit warnings to the contrary (e.g., Heidegger, 1993, §34, p. 167; §59, p. 295).

${ }^{12}$ I.e., that by which possibility is possible for us (see Heidegger, 1993, §53, p. 262); our Freisein für die Freiheit (§40, p. 187); our ability "to choose choice" (§54, p. 268); our "wanting to have a conscience" ( $§ 58$, p. 288). Cf. Kierkegaard, 1912, 36; Kant, 1999, Ak. 4:452 (in preparation to answer the question, "Wie ist ein kategorischer Imperativ möglich?"): "Nun findet der Mensch in sich wirklich ein Vermögen etc."; Nietzsche, 1968, §11, p. 18: "Wie sind synthetische Urteile a priori möglich? fragte sich Kant,- - und was antwortete er eigentlich? Vermöge eines Vermögens."

13 See Husserl, 1922, $\S 17$, p. 32 and $\S 9$, p. 19, and, for Tatsachen (" 'matters of fact' in D. Hume's sense"), Introduction, p. 3.

${ }^{14}$ This reading is in agreement with Friedman's: see 2000, 67 n. 81 (although Friedman's interpretation of Husserl is quite different from my own). Others have also noted the connection between Carnap and Husserl to one degree or another. See Mayer, 1992; Richardson, 2003a and 2003b, 175, 66 n. 5; Sarkar, 2003; Roy, 2004.

${ }^{15}$ Cf. Carnap's use of syntaktische Kategorie, together with thoroughly Husserlian lists of examples $(1931,226,228)$.

${ }^{16}$ In the verificationist, methodologically solipsistic system of the Aufbau and the "Überwindung," the same reduction serves both of these purposes. In later versions of his system, where Carnap abandons both verificationism and methodological solipsism, metalogic is still responsible both for unifying science and for establishing the legitimacy (empirical meaningfulness) of its concepts, but not by the same procedure. (See, for the earliest version of this, Carnap, 1932, 432-3, 440, 453, 457-9.)

17 See also Carnap, 1922, 5; 1932, 433.

${ }^{18}$ In his "Intellectual Autobiography," Carnap describes this as a view about language which developed in the Vienna Circle in opposition to Wittgenstein, "first tentatively, then more and more clearly" (Carnap, 1963, 29). But the Aufbau already expresses it quite explicitly: see $\S 19$, pp. 24-5; §138, pp. 183-4; §141, pp. 188-9. 
${ }^{19}$ Cf. Conant, 2001. Conant's paper is an excellent contribution to the difficult task of interpreting Wittgenstein, but, in my view, underestimates the difficulty of interpreting Carnap, who, though he (as he well knew) was no Wittgenstein, nevertheless has his own subtleties.

${ }^{20}$ And cf. Carnap, 1963, 22: "[Neurath] shared our hopeful belief that the scientific way of thinking in philosophy would grow stronger in our era."

${ }^{21}$ See also Carnap, 1963, 3: "My parents were deeply religious; their faith permeated their whole lives. My mother used to impress upon us that the essential in religion was not so much the acceptance of a creed, but the living of a good life... This attitude made her very tolerant toward people with other beliefs." It is likely that Carnap heard this view about "the essential in religion" in a relatively sophisticated form: his mother, Anna Carnap nee Dörpfeld, was, as he relates, the daughter of the educational and theological thinker Friedrich Wilhelm Dörpfeld, and a published author in her own right: see her 1903. Dörpfeld, a follower of Herbart (i.e., a certain kind of quasi-Kantian), claimed that both orthodox and liberal theology had made the same mistake, thanks to lingering Scholasticism and "Spinozan-SchellingianHegelian metaphysics": the mistake of subordinating ethics to dogmatics (see his 1895).

See further document ASP/RC081-05-06, an outline for a vaguely Aufbau-like work dated Apr. 27, 1921 and titled "Analyse des Weltbildes." The document begins with the following "Vorbemerkungen": "Value of error (= harmfulness of truth). 2 constituent parts of religion: 1 ) life-feeling, 2) intuitions (with which the life-feeling is connected [verknüpft]). 1) can therefore be shaken [erschüttert] at the same time as (2): example: effect of Darwinism etc. on the peasants ... Solution: half-truth confuses, whole clarifies. And if one doesn't know whether one will press through [durchdringen] (or lead through) to the whole??"

${ }^{22}$ That Nietzsche's ambiguous talk about "philosophers of the future" is aimed at securing our (untimely) autonomy in the present is most explicit in its earliest form (see Nietzsche, 1981, 226-7), but it is clear enough in later versions, as well. (The general idea is: we give ourselves a law by assigning to ourselves the task of producing our own masters.)

For further evidence of Nietzschean influence at this point, see ASP/RC08-05-01, "Vom Chaos zur Wirklichkeit," dated July 12, 1922 and famously labeled by Carnap as "der Keim zur Konstitutionstheorie des 'Log. Aufbau.' " In the first paragraph Carnap speaks of "great inconsistencies [Unstimmigkeiten] which extend through the whole realm of actuality," in the face of which we are prompted to a "will to a reordering which overcomes them" (Wille zu einer sie überwindenden Neuordnung). "It is this will to reordering," he continues, "which permits epistemological reflection [Überlegung] and the fictions which appear therein, of chaos as starting point and of the ordering principles according to which the construction $[\mathrm{Bau}]$ occurs."

${ }^{23}$ A special case of this is that any a priori knowledge of cause and effect must derive from a free choice on our part. Carnap makes this point very early, and continues to make it later, as well: see 1922, 34-6; 56; 1924, 117; 1934, $\S 79$, p. 234-5; $\S 83$, p. 251; and (more clearly than the preceding) $1935,87$.

${ }^{24}$ See Carnap, 1974, §183L, p. 261, where he praises Wittgenstein's Tractatus as "very valuable both due to its logical derivations and due to the ethical deportment [Haltung] which speaks from it," and then quotes the famous sentence from the Foreword.

${ }^{25}$ Whatever else one may say about Quine's understanding, or lack thereof, of Carnap, he seems to have understood very well what was, for Carnap, the most important point: that language is both an ordinary empirical object and the object of autonomous choice. Unsurprisingly, given the political differences between the two, he then made it his business to attack Carnap precisely there, from every possible angle (e.g., radical translation, truth by convention, the analytic/synthetic distinction).

${ }^{26}$ Quoted in Carnap, 1931, 229; Carnap's ellipses, Heidegger's emphasis (according to Carnap, though it does not match the emphasis in recent editions of Heidegger's text). 
${ }^{27}$ Carnap, 1931, 230.

${ }^{28}$ See the definition of "content" in Carnap, 1934 (§49, p. 128).

29 The role Heidegger himself assigns to it is that it is a source, if not the source, of philosophical error. See, in addition to the remark about "pseudoproblems" cited above (Heidegger, $1993, \S 44$ b, p. 220), any of Heidegger's numerous historico-etymological analyses of philosophical terminology. In the Introduction to Sein und Zeit, for example, he devotes a long passage to explaining the meaning of Phänomenologie through an analysis of the (supposed) original meanings of the Greek words phainō and logos (ibid., §7, pp. 28-34). The implicit point is that Husserl goes astray by using the term without accountability to those original Greek meanings-i.e., by using it in a linguistically innovative manner; by taking advantage of the fact that language, in the mouth of das Man, so easily accommodates new terms and definitions.

${ }^{30}$ Such a reading appears to be behind the assumption — common to Conant, Käufer, and many other interpreters - that Carnap regards Heidegger as having fallen into error unwittingly, through some kind of laziness or carelessness or stupidity. But Carnap does not say that and, based on the available evidence, did not think it. See especially the passages from Carnap's diary cited by Friedman (2000, 7-9), in support of essentially the same point I am making here.

${ }^{31}$ According to Kant, what relative goods lack is a good will, which would make them allgemein-zweckmäßig (1999, Ak. 4:393). On relative versus absolute ends, see Carnap, 1963, 83.

32 This same draußen appears much later in the English phrase "external questions" (which, according to Carnap, are not really questions, or not theoretical questions, at all).

${ }^{33}$ See Kierkegaard, 1912, 8, 36, 57-8, and Heidegger, 1993, §40, p. 190 n. 1.

${ }^{34}$ For this use of Erschütterung, see Heidegger, 1993, $\S 51$, p. 254, n. 1.

${ }^{35}$ Cf. Friedman $(2000,19)$, who understands this quite differently.

${ }^{36}$ See, e.g., Friedman, 2000, 12; Käufer, 2005, 141, 146, and (implicitly) 2001, 471.

${ }^{37} \mathrm{See}$, for the clearest examples, in addition to the Afterword to Heidegger, 1969 (first published with the fourth edition, 1943), also the Introduction to that work (first published with the fifth edition, 1949), as well as 1983, 227-8 (lectures delivered in 1935) and "Überwindung der Metaphysik" (Heidegger, 1954), an essay dating from 1936-46.

\section{References}

Carnap, A.: 1903, Friedrich Wilhelm Dörpfeld: Aus seinem Leben und Wirken. Gütersloh: Bertelsmann.

Carnap, R.: 1922, Der Raum: Ein Beitrag zur Wissenschaftslehre, No. 56 in Kant-Studien Ergänzungshefte. Berlin: Reuther and Reichard.

Carnap, R.: 1924, 'Dreidimensionalität des Raumes und Kausalität: Eine Untersuchung über den logischen Zusammenhang zweier Fiktionen'. Annalen der Philosophie und philosphischen Kritik 4, 105-30.

Carnap, R.: 1931, 'Überwindung der Metaphysik durch logische Analyse der Sprache'. Erkenntnis 2, 219-41.

Carnap, R.: 1932, 'Die physikalische Sprache als Universalsprache der Wissenschaft'. Erkenntnis 2, 432-65.

Carnap, R.: 1934, Logische Syntax der Sprache. Vienna: Springer.

Carnap, R.: 1935, Philosophy and Logical Syntax; reprinted New York: AMS Press, 1979.

Carnap, R.: 1963, 'Intellectual Autobiography'. In: P. A. Schilpp (ed.): The Philosophy of Rudolf Carnap. La Salle, Illinois: Open Court, pp. 3-84. 
Carnap, R.: 1974, Der logische Aufbau der Welt. Hamburg: Meiner, fourth edition.

Carroll, L.: 1872, Through the Looking-Glass and what Alice Found There.

Conant, J.: 2001, 'Two Conceptions of Die Überwindung der Metaphysik: Carnap and Early Wittgenstein'. In: T. McCarthy and S. C. Stidd (eds.): Wittgenstein in America. Oxford: Clarendon, pp. 13-61.

Dörpfeld, F. W.: 1895, Zur Ethik, ed. G. von Rohden, Vol. 11 of Gesammelte Schriften. Gütersloh: Bertelsmann.

Friedman, M.: 2000, A Parting of the Ways: Carnap, Cassirer, and Heidegger. Chicago: Open Court.

Heidegger, M.: 1954, 'Überwindung der Metaphysik'. In: Vorträge und Aufsätze. Pfullingen: Neske, pp. 67-95.

Heidegger, M.: 1969, Was ist Metaphysik? Frankfurt: Klostermann, tenth edition.

Heidegger, M.: 1983, Einführung in die Metaphysik, Vol. 40 of Gesamtausgabe. Frankfurt: Klostermann.

Heidegger, M.: 1993, Sein und Zeit. Tübingen: Niemeyer, seventeenth edition.

Husserl, E.: 1922, Ideen zu einer reinen Phänomenologie und phänomenologischen Philosophie; reprinted Tübingen: Niemeyer, 1993, second edition.

Husserl, E.: 1956, Erste Philosophie, ed. R. Boehm, Vol. 7, no.1 of Husserliana. The Hague: Nijhoff.

Husserl, E.: 1988, 'Kritik der Kantischen Ethik'. In: Vorlesungen über Ethik und Wertlehre, 1908-1914, ed. U. Melle, Vol. 28 of Husserliana. Boston: Kluwer.

Kant, I.: 1990, Kritik der reinen Vernunft, ed. R. Schmidt, Vol. 37a of Philosophische Bibliothek. Hamburg: Meiner, third edition.

Kant, I.: 1999, Grundlegung zur Metaphysik der Sitten, ed. B. Kraft and D. Schönecker, Vol. 519 of Philosophische Bibliothek. Hamburg: Meiner.

Käufer, S.: 2001, 'On Heidegger on Logic'. Continental Philosophy Review 34, 455-76.

Käufer, S.: 2005, 'Logic'. In: H. L. Dreyfus and M. A. Wrathall (eds.): A Companion to Heidegger. Malden, MA: Blackwell, pp. 141-55.

Kierkegaard, S.: 1912, Der Begriff der Angst: eine simple psychologisch-wegweisende Untersuchung in der Richtung auf das dogmatische Problem der Erbsünde, tr. C. Schrempf, Vol. 5 of Gesammelte Werke. Jena: Diederichs.

Mayer, V.: 1992, 'Carnap und Husserl'. In: D. Bell and W. Vossenkuhl (eds.): Science and Subjectivity: The Vienna Circle and Twentieth Century Philosophy. Akademie Verlag, pp. 185-201.

Nietzsche, F.: 1968, Jenseits von Gut und Böse, Vol. 6, no.2 of Werke. Berlin: de Gruyter.

Nietzsche, F.: 1981, 'Schopenhauer als Erzieher'. In: Unzeitmäßige Betrachtungen. Frankfurt: Insel.

Richardson, A. R.: 2003a, 'Conceiving, Experiencing, and Conceiving Experiencing: NeoKantianism and the History of the Concept of Experience'. Topoi 22, 55-67.

Richardson, A. R.: 2003b, 'The Geometry of Knowledge: Becker, Carnap, and Lewis and the Formalization of Philosophy in the 1920s'. Studies in History and Philosophy of Science 34, 165-82.

Roy, J.-M.: 2004, 'Carnap's Husserlian Reading of the Aufbau'. In: S. Awodey and C. Klein (eds.): Carnap Brought Home. Chicago: Open Court, pp. 41-62.

Sarkar, S.: 2003, 'Husserl's Role in Carnap's Der Raum'. In: T. Bonk (ed.): Language, Truth and Knowledge: Contributions to the Philosophy of Rudolf Carnap. Boston: Kluwer.

Schuhmann, K.: 1977, Husserl Chronik. The Hague: Nijhoff. 